\title{
Social Innovation and creativity in cities: a socially inclusive governance approach in two peripheral spaces of Barcelona
}

\author{
Marisol García, Santiago Eizaguirre and Marc Pradel* \\ University of Barcelona
}

\begin{abstract}
Culture and creativity make two contributions to sustainability in cities: (1) Economic impact, related to the economy and the marketing of the city, involving consumers, jobs, creative clusters, technology, mobility, infrastructures and (2) urban regeneration concerned with social cohesion, socially creative initiatives and local citizenship with sustainability objectives. We provide a critical appraisal of the first and concentrate on the second. The paper focuses on how collective actors are capable of creating new spaces for public debate and daily practices that reinforce community life and citizenship. In some cities creation of spaces for cultural creativity has been the result of 'bottom-linked' innovation. Two examples are examined in two peripheral districts of Barcelona. These are: Ateneu Popular de 9 Barris (AP9B) and Fabra i Coats. Both are currently managed by a hybrid partnership between public administration and civil society organizations. The 'bottom-linked' approach to social innovation recognizes the centrality of initiatives taken by those immediately concerned, and also stresses the need for institutions that enable and sustain such initiatives through sound, regulated and lasting practices and through clear citizen rights, guaranteed by the functioning of the democratic state (Pradel, García \& Eizaguirre, 2013).
\end{abstract}

Key words: creativity, culture, social innovation, social cohesion, bottom-linked.

*A previous version of this paper was presented at the Osaka City University International Symposium, Inclusive Creative Cities and Cultural Diversity. July 2014. Marisol García wants to thank participants for the feedback and specially Hiroshi Okano for his invitation to participate in the Symposium.

The authors want to thank the anonymous reviewers for the constructive comments to this paper. They also thank Jordi Hereu (Major of Barcelona 2006-2011); Sergi Díaz. (Direcció de Cultura de Proximitat. Institut de Cultura de Barcelona); Pere Fernández (President Amics de la Fabra); Carmen Fructuoso and members of Ateneu Popular 9Barris. All have provided rich information in interviews. 


\section{Introduction}

There are at least two distinctive traditions of 'seeing' cities, one focuses on human development, individual and collective creativity/humanity. In this tradition the city as an agora includes active citizens and offers possibilities for innovative responses to social and economic needs. In other words, the polis constitutes the arena for claims for new political and social rights (Isin, 2000; García, 2006; Sassen 2010). An Alternative view sees the city as a machine for the production of economic wealth and consumption, where individual creativity is a key engine for competitiveness and more recently- where cultural expressions in central spaces are elements of city branding (Logan and Molotch, 1987; Scott, 2008; Pratt, 2010). This view of the city has been contested (Zukin \& Braslow, 2011; Pratt, 2011; Pratt \& Hutton, 2013) and the present contribution seeks to intervene in the recent debates published in this Journal.

In this article we focus on how collective actors have transformed urban spaces for cultural creativity in two traditional working class neighbourhoods in Barcelona. We argue that these acts of citizenship and the type of governance of these collective spaces constitute 'bottom-linked' social innovation. As previous research has concluded, 'bottom-linked' social innovation develops when citizens' collective initiatives result in agreements with local institutions that enable and sustain such initiatives through sound, regulated and lasting practices. In some instances such practices evolve into citizen rights, guaranteed by the functioning of the democratic state (Pradel, García \& Eizaguirre, 2013).

There is a considerable literature on urban governance (Pierre and Peters, 2012). It is arguable whether this literature should be simply applied to the various approaches to cultural governance. But it would require another paper to enter into this discussion. More relevant to this contribution is the analysis of governance of urban regeneration that develops in inner-cities and in modern peripheral neighbourhoods in post-industrial cities (Landry, 2000; Buck et al., 2004; Healey, 2004; Miles and Paddison, 2005; McCarthy, 2006). This goes in particular for the governance of innovative practices.

In a recent publication Degen and García (2012) analyzed the transformation of the relationship between the use of culture and modes of governance in the urban regeneration of Barcelona. A city that "took an urban-design, cultural-planning and creative-quarter approach" as a way of regenerating industrial spaces with a particular governance style based upon strong citizen support also used culture as a method of social cohesion and as an expression of citizenship up until the mid 2000s. Citizens maintained a constructive dialogue with institutions in culturally led urban 
regeneration in the 1980 s and early 1990 s although by the turn of the century local residents contested the urban renewal of the 'creative district 22@' denouncing signs of gentrification (Marti \& Pradel 2012; Benach, 2000).

Centrally located creative districts attract ample attention in urban literature in general, and in Barcelona in particular, but there is a lack of studies on cultural and social innovation with organized citizens as main actors in non-central districts of Barcelona. For this reason we present two cases: the Ateneu Popular de 9 Barris (AP9B) in Nou Barris and Fabra i Coats in Sant Andreu. We argue that collective creativity linked to culture and urban regeneration has also developed in these two peripheral districts of Barcelona favouring social cohesion and sustainability. We think that there are lessons to be learned by examining these alternative models of governance and cultural regeneration practices initiated by active citizens and later supported by the local administration. These cases contrast with top-down and prestigious, high-culture intervention in the types of activities they create and provide for the neighbourhood. Moreover, these cases show alternative governance strategies and therefore offer a useful contrast of governance approaches to cultural regeneration showing that not all cultural and urban regeneration needs to be the same.

As has been pointed out elsewhere (García \& Judd, 2012) there is a strong emphasis in the literature and in policy discourses on the importance of human capital and more specifically on the emergence of a "creative class" as a key factor in urban regeneration and economic development. Urban creativity - although intrinsic to the prosperity of historic Athens, Florence, Vienna or Paris to mention some European cities with distinctive creative historical landmarks - has become the central concern of two debates worth remembering here. One critical debate concerns the innovative work of Richard Florida (2002) of what comprises the 'creative city', on who are the main actors of creativity and on what are the consequences of incorporating Florida's assumptions - the power of culture and the creative class- in policy making; the most familiar being the promotion of heritage in attracting tourism (Pratt, 2010; 2011). The other debate questions the desirability of implementing the competitive-city assumptions derived from Florida's work for guiding urban regeneration in cities since the use of artists' clusters for urban renewal touches land values and often results in gentrification that threatens traditional communities as well as the low-income cultural producers (Zukin \& Braslow, 2011).

In line with these critical debates we look at alternative creative actors that have appeared from within traditional working class urban communities. The power of culture these actors embody contrasts with Florida's vision since they have not distinguished themselves as members of a professional cultural class; secondly, what they do is largely orientated to the collective needs of the neighbourhood and thirdly, 
they are supported by the workers communities from the start and continue to be acknowledged by them. Therefore, the creativity these actors manifest is socially, culturally and economically embedded. As Pratt has argued this notion challenges the universalistic notion of creativity and of the creative city $(2011,124)$.

We see the cases presented in this paper as in line with the UNESCO declaration of cultural diversity (Pratt, 2011) and the programs supported by this international organization. UNESCO, promotes culture as a key resource to address economic and social dimensions of poverty and to provide innovative solutions to complex issues. According to this organization, in a globalized world culture and creativity become key drivers if they are used as opportunities for exchange and mutual enrichment. Culture is seen as a force for sustainable development because it helps promote social cohesion and youth engagement ${ }^{1}$. In Europe, the European Union programme for the culture and creative sectors 2014-2020 highlights the importance of these sectors for the European economy in generating growth and jobs. ${ }^{2}$ Thus creativity, culture and sustainable development have become acknowledged as crucial for social cohesion in cities.

Of late, the notion of sustainability has come to the fore in European cities, and not only there. Global summits and world-wide reports have advanced recommendations on life-style changes, the ability of future generations to meet their own needs and the necessity to make economic development, social justice and the environment work together. These messages from the UN World Commission for Environment and Development (Brundtland Report) also address urban sustainability, which -it says- requires not only more effective use of technologies and mobility systems to achieve environmental imperatives, but also demands creating social cohesion in neighbourhood communities and addressing political issues of social justice (Cook and Swyngedouw, 2012, 1961-1963).

Urban sustainability, in the sense used in this article, means the support of institutions for the persistence of communities and involves applying urban

\footnotetext{
${ }^{1}$ The potential impact of culture and creativity is large. Culture and creative industries are among the most rapidly growing industries in the world representing an estimated global value of US\$ 1.3 trillion (UNESCO). http://en.unesco.org/post2015/power-culture-development (accessed 21 June 2014)

2 Creative Europe provides $€ 1.46$ billion over seven years to strengthen Europe's cultural and creative sectors. Along with international and European institutions, national, regional and municipal institutions provide support in different ways -from direct finance to tax exemption.

http://bookshop.europa.eu/en/creative-europe-

pbNC0113437/;pgid=y8dIS7GUWMdSROEAIMEUUsWb0000WRgV009r;sid=13Kg3VXilOagngZF1Z8eifHOKGmDhiByQA=?CatalogCategoryID=ANIKABstUgUAAAEjCJEY4e5L (accessed 22 June 2014)
} 
regeneration strategies such as the preservation of open public space, the enhancement or creation of public spaces for collective uses and access to housing. An urban sustainability agenda raises issues that concern active community groups involved in urban struggles and in the exercise of bottom-up strategies in the cultural sphere. These strategies may evolve from the values and experiences of inhabitants of neighbourhoods (including those peripherally located), whose voices are not always incorporated in top-down city regeneration agendas. Empirical studies show, however, that urban sustainability policies that rely on building ostensible politics of consensus can easily ignore the living conditions of minorities or marginalised groups. In their examination of urban sustainable development in Worcester Krueger and Buckinham argue that economic and environmental concerns should 'sit completely within social justice concerns' (Krueger and Buckinham, 2012, 486-501).

However, consensus is not always present throughout. For example, bottom-up initiatives in culture infrastructure that involve occupation of spaces by members of local communities may go through a period of tensions with local governments. These tensions, however, may evolve into cooperation in bottom-linked practices if institutions develop the capacity to deal with conflict, making room for dissent (Eizaguirre et al., 2012).

In the following sections of this article we discuss first the role of culture in urban sustainability, then the importance of social innovation in maintaining social cohesion, thirdly we analyse the contribution of two socially innovative spaces in the periphery of Barcelona, and finish with some concluding remarks.

The role of culture and in urban sustainability: social inequality and the question of redistribution

Culture has been widely recognized as an instrument to meet the social, economic and political objectives of the city (Miles \& Paddison 2005, Zukin 1995). As Basset et al. (2005) suggest, the notion of culture as an anthropological notion that refers to a way of life has been extended to the field of economic development in contemporary capitalism by the "culturalization of the economy"'. This means that urban regeneration policies and redevelopment actively support the expansion of cultural strategies in two ways: (1) Using culture as a factor of economic development in the post-industrial city. This involves the marketing of the city to consumers - locals and tourists -, job creation, creative clusters and high-tech (mobility) infrastructures; (2) Using culture as a protective social veneer for urban redevelopment as it conveys the impression that by its inclusive nature it counteracts pure economic considerations in such a way that social exclusion is prevented. This use can involve urban regeneration 
concerned with social cohesion, socially creative initiatives, local citizenship and sustainability. As a result:

(1) City leaders seek to enhance the competitive position of cities in a global economy through focusing explicitly on culture and identity, reflected as much in the physical transformation of the city as in the development of a distinctive cultural life in the city (Zukin, 1995; Degen, 2008).

(2) Urban policy makers often relate place competitiveness to social cohesion (Fainstein, 2001; Buck et al., 2004) but we feel that more nuanced study is needed that pays attention to the ways neighbourhoods can successfully maintain social cohesion in large cities.

These two dimensions (competitiveness and social cohesion) are part of a complex relation between market and state policies, which manifest themselves differently in different parts of the world. In the United States, urban regeneration policies linked to culture consist of two major elements: a close collaboration between government and business and urban-led (bottom-up) intervention of policy with a strong competitive aim. Savitch and Kantor (2002) have identified the market-centred strategies of US urban regimes as attempts to induce investment through low taxes, public subsidies through land grants, loose regulation, and publicly funded infrastructure. In contrast, in continental Europe these authors identify social-centred policies that rely heavily upon formal planning and impose requirements and restrictions on investors, such as the provision of public amenities. Moreover, in European cities social-welfare policies have been incorporated aiming to spread the social benefits of urban regeneration.

In the United States the influential theoretical and empirical contributions of Florida (2002) have indicated the importance of human capital and more specifically the emergence of a "creative class" as a key factor for economic development. Although related to labour-market analysis, talent becomes central and interacts with other factors, such as the openness and tolerance of the urban environment and social diversity (Florida, 2002). In the significant role Florida gives to creativity and innovation for the economic development of cities, the identity of place is often reduced to ways of life of an upper middle class located in specific parts of the city, where most culture infrastructures are located. As Scott highlights "the culture-generating capabilities of cities are being harnessed to productive purposes, creating new kinds of localized advantages with major employment and income-enhancing effects." (1997, 335). Florida's approach understands the "creative class" as the element producing resurgent cities, as competitive firms tend to locate where creative professionals concentrate giving centrality to particular urban environments, often located in central districts. 
Although empirical studies have shown the weakness of these assumptions (Storper and Manville, 2006, 1251; Pratt, 2010; Storper, 2013, 70-71) municipal leaders of European cities have followed Florida. In recent years mayors of European cities have imitated the US drive to culture-led city competitiveness. Increased competition between cities has been crucial in stimulating policy shifts, supported by private-sector organized interests (Crouch \& Le Galès, 2012, 416). This shift is visible in the locations and character of infrastructures to enhance the competitive capacity of cities. The overall effects for the cities as "places" for economic competition are the abandonment of equity as a guiding principle to construct a just city (Fainstein, 2005; García, 2006) and the neglect of alternative cultural-creative dynamics within "fragile" neighbourhood and minority communities (Moulaert \& Nussbaumer, 2005). Such disregard, we argue, challenges sustainable neighbourhoods and the social cohesion of cities.

While public investment is visibly concentrated in mega-projects such as Olympic sites (Fainstein and Díaz, 2008, 759-767) or knowledge-economy industries the visibility of different social groups in central urban zones has shifted towards greater presence of upper and middle class groups to the detriment of others. As a result, 'the look and feel of cities reflect decisions about what - and who - should be visible and what should not, concepts of order and disorder, and on uses of aesthetic power' (Zukin, 1995: 7). This socio-spatial fragmentation is not new. Historically, Engels first detected similar outcomes as a result of biased urbanism in Manchester in the 19th Century and Lefebvre theorized it in Paris in the 1960s. What is new is the emphasis on culture and creativity and the social fragmentation implied as a matter of fact.

The consequences of these policies for the creative city in terms of social inclusion and spatial segregation have been widely analyzed. In first place, different authors have underlined the role of culture-led developments for the attraction of 'the creative class' as mechanisms fostering gentrification and social exclusion (Evans, 2009; Pratt, 2011; Zukin and Braslow, 2011)? and the role of creative workers and artists organizing social contestation against such projects (d'Ovidio and Pradel, 2012; Martí-Costa and Pradel, 2012; Novy and Colomb, 2012). Secondly, attention has been directed to policy-makers' attempts to use culture and creativity as tools for social inclusion in neighbourhoods (García, 2004; Jakob, 2010; Sánchez Belando, 2015; Tremblay and Pilati, 2013).

Susan Fainstein has asked the relevant question of whether it would be possible to envisage creativity and innovation with a larger societal participation beyond just the "creative core?" (Fainstein, 2005, 87). If in the European context the relatively strong welfare-state tradition (although uneven) has meant that the concept of the Just City remains a respectable notion, what might be "a more inclusive creative 
society" today? Is it possible to develop alternative cultural capabilities apart from the market-led competitive drive? And what types of social agency are emerging in cities other than the creative few?

Creativity is expressed not only individually, but also collectively in cities, where community sovereignty, autonomy, and solidarity receive their full meaning. It is the locus of everyday life - of perception of, and mobilization around local issues - that produces locality; where collective identity and sense of place are socially constructed, and livability is defined. The local can be seen as a privileged and empirical entry point for understanding the modalities of social cohesion through creativity and social innovation, spatial change, new policy initiatives, or collective action (Miciukiewick et al. 2012, 1858). Following Miles (2005), the recognition of the cultural manifestations and possibilities of everyday lives is probably more economically and socially sustainable than pursuing a "world city" image based on flagship cultural institutions such as the Tate Modern in London or the Guggenheim in Bilbao.

The global economic free-fall from 2008 has undermined the economic base of large metropolises in many regions of the world, and necessitates the countering of these top-down crises with bottom-up strategies, strengths and solutions (Fainstein, $2010,180)$. But while the financial crisis and austerity policies have undermined the continuity of many projects of urban culture regeneration and public investment in culture, there is an uneven impact of the crisis in the creative and knowledge industries (Pratt \& Hutton, 2013). Moreover, European Union programs, national and regional governments are supporting creativity and social innovation as ways to improve social cohesion in European cities (Oosterlynck et al., 2013). A change of urban design and its better coordination, as well as transport planning, combined with recognition and support for social innovation emerging in neighbourhoods may result in a better overall strategy for maintaining social cohesion.

\section{Social innovation (SI) and cultural creativity}

Social innovation, a widespread concept, can refer to processes that generate: a) the provision, in response to social needs, of resources and services; b) the development of trust and empowerment within marginalised populations; $c$ ) the transformation of the very power relations that produce social exclusion through a change in governance mechanisms (Moulaert et al., 2013). Actors promote social innovation in many ways. Public actors, for example, can innovate promoting new forms of organisation and coordination, and/or more openness to other actors in the provision of services and resources. For example, public institutions may support culture as collective resource. Private actors, such as companies promoting the social economy, can socially innovate through new forms of trust and relations between citizens and by developing new forms of economic exchange. Finally, organised citizens who disagree with mainstream

policy formulations can put forward alternative ways of addressing new risks of social 
exclusion (in relation to education, housing and city life) disregarded by public and market institutions. Often, actions intersect, and social innovation occurs when there is a creative collaboration between public actors or market agents and civil society organisations pursuing the empowerment of citizens and a change in social exclusion dynamics (Pradel, García \& Eizaguirre, 2013).

Various thoughts on social innovation have fed current debates on creativity and social cohesion in cities. Basically, these are four, as summarized below.

First of all, social innovation concerns not just outcomes, but processes of constructing innovative practices as well - especially in the social relations between individual actors and groups (Moulaert et al. 2013, 47; Klein et al. 2014). Thus the internal governance structures of innovative projects may work with alternative values that are brought into the public realm. This implies that social-innovation research should also focus on how social innovation processes and strategies happen.

An example is École Nationale du Cirque, the Tohu in Montreal, where various organizations (Cirque du Soleil, En Piste, and, also in the same district, a residential centre for artists in Montreal) have created a local compound of creativity. This creative ecosystem hosts artists and cultural practices. Moreover, the Tohu carries out activities with an important social dimension, which seek to augment the cultural capability of the local community. Not only does the Tohu aim at integrating visions of the community, but it is the participatory approach from the beginning of the development of the site, which prompts human development and social interaction (Temblay and Pilati, 2013, 73). From a governance perspective, the Tohu group also collaborates with major territorial stakeholders and develops projects in collaboration with the City of Montreal and several other organizations.

A second important consideration is the 'bottom-linked' approach to social innovation. This recognizes not only the centrality of initiatives taken by those immediately concerned, but also the need for the support of institutions that enable and sustain such initiatives through sound, regulated and lasting practices (García 2006; Pradel et al., 2013; Moulaert et al., 2013, 115-16). Sustaining social innovation involves identifying budgets, teams and other resources such as legislation. A further step is the constitution of social rights, although social innovation not always achieves this. Outcomes can be: recognition and support from public authorities for innovative citizen practices, recognition of cultural diversity and empowerment of people formerly socially excluded. Several possible impacts of SI on policy-making are: (a) to introduce changes in the definition of a policy problem; (b) to introduce changes in policy-making processes; (c) to introduce changes in policies and their results. Often institutionalization of this kind requires that other scales of governance (up-scaling) beyond the local assume responsibility for maintaining or improving welfare resources. 
This question is particularly relevant in the current economic and political context of welfare state retrenchment and liberalization of social services.

Third, socially innovative actions may be institutionally embedded as well as territorially reproduced as transferable experiences. Discourse on sustainable development long neglected this social dimension. But through the implementation of Local Agenda 21, together with other planning instruments, sustainable development gradually reached the local level and moved towards more territorialized/grounded strategies. Adopted at the 1992 Earth Summit, LA21 entails a societal search for alternative ways to mobilize local resources to achieve sustainable development ${ }^{3}$. (Mehmood \& Parra, 2013, 53-62). Institutionalization of LA21 requires innovation in governance incorporating new actors and projects. However, there are dangers of falling into a 'localism trap'. This is why research on social innovation emphasizes institutionalization and "up-scaling" from the local to the national scale. Scaling also involves diffusion and inspiration, critical in spreading an idea or practice. When scaling involves implementing legal and regulatory devices (such as rights to schooling) to embed change it is possible to talk of systemic change (Young Foundation, 2010).

Fourth, culture and creativity can do more than stimulate the economic competitiveness of cities. The incorporation of social innovation into the debate can offer an alternative perspective based on empirical studies of projects "that are social in their ends as well as in their means" (Oosterlynck et al., 2013, 2). Instead of focusing on 'the creative few' of the 'creative cities' discourse, social innovation analysis involves catching the social learning processes involved in cultural production. We also discern the role social innovation plays in the movement to counteract the overwhelming role played by markets and commodification processes (Mingione \& Vicari, 2014) in the present phase of capitalist development, where we see markets producing social exclusion for larger sectors of the population. Innovations are always contextual and relative to places. Thus innovative projects in some cities may not appear as such in other cities. What matters is the social and cultural processes they develop, and this includes stimulating innovation in governance.

Socially innovative projects can also contribute to the social sustainability of neighbourhoods or cities through maintaining social cohesion (Tremblay and Pilati, $2013,70)$ in the direction of increasing social capital, providing resources for empowerment and bottom-up organization. Thus, developing sustainable urban creativity requires more than the mere presence of 'creative people'. "Creativity needs to be mobilized and channeled" in order to be sustainable so that it can develop into

\footnotetext{
${ }^{3}$ The full text of Agenda 21 was made public at the UN Conference on Environment and Development (Earth Summit), held in Rio de Janeiro on June 13, 1992, where 178 governments voted to adopt the programme. In section I on Social and Economic Dimensions the objectives include combating poverty, promoting health, achieving a more sustainable population.
} 
practical forms of learning and innovation.' (André et al., 2013, 245). Above all social innovation requires a change in governance perspective. Local authorities should be advised to acknowledge that creativity is embedded in society. Their discourses on creativity can be widened by incorporating social innovation in the acknowledgment of the worth of diversity and tolerance ${ }^{4}$, particularly regarding civil and human rights issues, but also regarding social rights, for example, in housing. Especially in districts in which changes in land values cause expulsion of individuals. Thus, local authorities and policy-makers in general should be more receptive to the role social innovative practices and projects can have in more social-justice oriented planning (Fainstein, 2010).

\section{Social Innovation in two peripheral neighbourhoods in Barcelona}

As we mentioned in the introduction, urban regeneration of Barcelona used culture and creativity to enhance citizen participation and social innovation. City leaders implemented socially cohesive urban policies using arts and culture (Degen \& Garcia, 2012; Rodriguez-Morató, 2008). This fostered the creative capacities of individuals in their diversity and supported local identities and culture (Landry, 2000). But it also created a "brand" for the city worldwide (Miles, 2005). Barcelona has emerged as an example where a wide definition of creativity in a city's cultural policy can inspire citizens to engage in activities and collective projects as well as in individual creativity. Such a policy that is inclusive of bottom-up innovation can transform the governance process and its results (Healey, 2004).

Two socially innovative examples: Ateneu Popular de 9 Barris (AP9B) and Fabra I Coats

Whereas the inner-city and the new knowledge-economy district (22@) have been widely studied in Barcelona, non-central (traditionally peripheral working-class) neighbourhoods are often mentioned in passing without seeing them as "places" of cultural creativity. These districts do not attract investment resources for international competition and therefore do not appear in the city's branding publicity. However, districts like Nou Barris and Sant Andreu in Barcelona boast newly established cultural centers and spaces in former industrial buildings, where our two innovative cases are housed. The districts of Sant Andreu and Nou Barris are long-established working class areas which have become multicultural and socially mixed city areas where middleand working class interact with international immigrants arrived in the $20^{\text {th }}$ century. This mix creates cultural diversity and innovative potential. However, the lack of centrality causes these places not to appear in the cultural programs of Barcelona as spaces of cultural consumption or tourist attraction. Despite this, given the investment

\footnotetext{
${ }^{4}$ Tolerance basically means disapproval plus acceptance. If I tolerate something or someone I am claiming that my disapproval is legitimate as well as my expression of that disapproval (Steven Lukes, 1971).
} 
of public funds in refurbishing old industrial sites in these areas, why should these reconstructed spaces not receive more visibility as good examples of collective cultural creativity? These districts offer good examples of social innovation in that they have created new modes of governance coordinating different social and institutional actors.

The districts of Sant Andreu and Nou Barris are located in north-east Barcelona. Both districts resulted from the growth of the municipality of Sant Andreu del Palomar, annexed to Barcelona in 1897. Population growth brought the administrative division of the area into two districts in 1986, Sant Andreu and Nou Barris.

The Sant Andreu district has a population of about 150,000 people in an area of 653 hectares and consists of seven neighbourhoods. The largest and oldest of these is Sant Andreu with 56,204 people ${ }^{5}$. During the second half of the $19^{\text {th }}$ century Sant Andreu del Palomar became the site of some of the most important factories in Barcelona. The largest factories, the Fabra $i$ Coats (textile production) and the Maquinista Terrestre and Maritima (MYM) (mechanical engineering) became the main production centres of the industrial neighbourhood. With the regeneration of the city from an industrial into a post-industrial urban metropolis these two large industries changed character. Today the old MTM is mainly a large commercial complex while the Fabra $i$ Coats building became a collective site for cultural and social initiatives emerging in the district ${ }^{6}$.

Barcelona City Council acquired the former Fabra i Coats factory in December 2005, when the factory closed after 175 years of activity. The premises were rehabilitated with public funding. The buildings were then occupied by the Factory of Creativity cultural centre, and other civic associations and welfare services. The occupation resulted from an open participatory process held in 2006 when a resolution was adopted to turn the central hall into a national and international benchmark space and to offer other spaces for the recreation of social-cultural relationships.

\footnotetext{
${ }^{5}$ In 2012 the district had a total of $26.3 \%$ of university graduates (18.1\% in Sant Andreu) and $24.9 \%$ who had completed secondary school. The foreign population in the district and the neighbourhood of Sant Andreu is $17.6 \%$ and $11.5 \%$ respectively. Of the total population of the district $46.7 \%$ were born in other cities than Barcelona in Spain. (Ajuntament de Barcelona, 2014). With the impact of the economic crisis in the city disposable family income has diminished from 82.4 to 74.1 from 2005 to 2011 (100 for Barcelona) indicating that this district has suffered in terms of reduction of income and employment. Finally the district has only two 3-star hotels with a capacity of 180 rooms but has four public libraries and two theaters.

${ }^{6}$ http//fabra i coats.bcn.cat/en; http://centredart.bcn.cat/es/
} 
The Nou Barris district has a population of about 167,175 people in an area of 800 hectares and consists of thirteen neighbourhoods ${ }^{7}$. This district developed from the 1950s onwards when thousands of workers from rural Spain (mainly South and North East) settled in Barcelona. The concentration of factory workers gave a strong collective consciousness to this district, also because the absence of services for almost two decades prompted a strong social solidarity and stimulated bottom-up strategies. From the mid 1990s the district has also welcomed large numbers of international migrants. What makes this district particularly relevant for our argument is its pronounced social creativity.

In January of 1977 around two hundred locals occupied a derelict asphalt plant in Nou Barris. Since then the Ateneu Popular 9Barris ${ }^{8}$, created in the old industrial premises, has become a referential cultural centre for the promotion of arts, especially circus arts. Conceived as a space for socio-cultural interaction open to citizenry and to local civic associations, this place has become important to the socio-cultural life of the neighbourhood. Moreover, after various episodes of conflict and negotiation between the organized residents managing Ateneu Popular 9Barris and the city council, the centre has gained considerable prestige. The city of Barcelona now recognises the Ateneu as a socio-cultural factory representing Catalonia at the international circus scene.

The social innovation and creativity of the cases

From the start Ateneu Popular 9 Barris was conceived as a cultural community centre for the neighbourhood, specially oriented to offer a space for the interaction of young people. Through the years the circus program has consolidated while preserving the original aim of improving the social and cultural life of its immediate urban context. Ateneu promotes participation, creativity and social transformation. This implies special attention to social development with the values of independence, autonomy, solidarity, respect, quality and engagement with the neighbourhood and the district.

\footnotetext{
7 The district had in 2012 a total of $10.7 \%$ of university graduates and $20.7 \%$ who had completed secondary school. The foreign population in the district is $17.0 \%$. Of the total population of the district $53.1 \%$ were born in other cities than Barcelona in Spain. (Ajuntament de Barcelona, 2014). With the impact of the economic crisis in the city the disposable family income has diminished from 68.5 to 61.6 from 2005 to 2011 (100 for Barcelona) indicating that this district not only has suffered in terms of reduction of income and employment, but also that the starting point was already below the city's average. The district has five public libraries as well as one 2-star hotel and one B\&B for a total capacity of 169 rooms.

8 "Nou" in Catalan means both 9 and "new". When the district was established it contained 9 neighbourhoods.
} 
As to governance, Ateneu Popular 9 Barris reached an agreement with the Barcelona City Council in the late 1980s after repeated conflict and negotiation. At that time the City Council acquired the part of the property belonging to the Spanish Ministry of Public Works and accepted to fund the rehabilitation of the building to become a cultural centre. The management of the building passed to a juridical entity - Associació Bidó de 9 Barris - (consisting of representatives of the neighbourhood associations). A permanent committee is drawn from this body, elected every two years in a public assembly. The committee performs every-day decision making and consists of five people working on a voluntary basis who meet weekly. They are supported by a team of project managers who work professionally on daily tasks. The centre's budget is financed for $60 \%$ by several public administrations. The other $40 \%$ is generated by the centre, which include training and exhibitions.

Bidó de 9 Barris is an active part of a network of associations working on cultural and social issues in the district ${ }^{9}$ and actively participates in a platform created with other civic associations that manage civic and cultural spaces in the city. This model of management and the relations between organized citizens and local administration has been highly innovative and has had an impact in the other organisations of the district and in other districts of the city ${ }^{10}$. Bidó de 9 Barris is, therefore, an example of social innovation in governance that scales-up to the city from the neighbourhood where it was originally created.

From the moment when in 2002 one of the buildings of the old textile factory Fabra i Coats, became a public library and cultural centre the rest of the derelict industrial site was seen by the neighbourhood as part of the collective patrimony. Thus when in 2005 the owners of the company sold the remaining factory premises to a developer leaders of the neighbourhood association as well as other local associations pleaded with the City Council to buy the site. Starting from the neighbourhood residents lobbied first the District councilor and then the City Mayor in favour of protecting the architectural and social patrimony of the old factory. A commission elaborated a document recounting the industrial and community history and the strong relation between the factory and the neighbourhood. The rehabilitated central part of the factory complex was designed to become a space for generating multidisciplinary artistic creation managed by the municipality through the Institute of Culture of Barcelona (ICUB). Other spaces of the factory complex have also been

\footnotetext{
${ }^{9}$ see http://www.ateneu9b.net/content/formem-part-de

10 In fact, the Ateneu Popular de Nou Barris has become a reference for social and neighbourhood movements, creating similar approaches to management in other buildings such as Can Basté, a civic centre of Nou Barris managed by the association Turó Acció socio-cultural (TASC), or the civic centre of Sant Andreu, which is managed by the Federation of entities L'Harmonia, in both cases in agreement with the city council.
} 
rehabilitated to host other civic associations, e.g. L'Associació d'amics de la Fabra (Association of La Fabra's Friends led by qualified personnel of the old industrial factory). In 2014 the Federation of associations L'Harmonia occupied another section of the rehabilitated premises. The transformation of Fabra $i$ Coats figured in the 2006 Strategic Plan of Culture of Barcelona ${ }^{11}$. Beyond meeting the needs of young local artists, the conversion plan also intended to attract young foreigners in order to enhance Barcelona's international profile. Teams of professionals are invited to come to the old factory to work on the development of festivals and other cultural activities. Fabra i Coats also works with Barcelona's cultural program of summer festivals.

The Fabra i Coats cultural centre represents innovative governance. The large industrial site accommodates and promotes the coexistence of different cultural and educational projects ${ }^{12}$. The factory complex of various buildings allows the development of multiple activities with different styles of management and different types of social actors and ways of governance. Two main governance dynamics are present: (1) Staff of the local administration (ICUB) manage a cultural space for exhibitions and art production within a city and international context, and (2) Bottomup and bottom-linked governance happens with local organized citizens in several associations (such as L'Harmonia) collaborating with institutions in an ad-hoc manner, within a context limited to neighbourhood or city. According to the needs of each project the governance configuration can be weighted more towards the institutions or the local associations. In both cases spaces were taken over aiming for community cohesion and social sustainability. Both Ateneu and Fabra i Coats experience a tension between two levels of action. There is the cultural project which intends to be a reference for the entire city as a space for creativity and cultural attraction. Alongside this there is a neighbourhood project where locals work on the improvement of social needs and community relations in their immediate local context. The cases differ in their origins. The Ateneu started as an occupation driven by neighbours. Fabra i Coats is based on a negotiated decision with public authorities, encouraged by interested local citizens, but driven by public agents

11 http://www.bcn.cat/plaestrategicdecultura/pdf/StrategicPlanBCN.pdf

\footnotetext{
12 September 2012 saw the inauguration of the first 600 square meters of an art exhibition centre. Two years later almost 2,000 square meters were ready to accommodate an array of activities, such as music, exhibitions, social innovation fairs and multimedia projects.
} 


\section{Conclusions}

The cases examined in this article constitute alternative models of governance to urban creativity and innovative ways to address urban regeneration. These projects go beyond individual creativity to actually providing (facilitating) material resources (spaces) and social resources (networks) not previously available or provided by the market or the state. To the extent these projects are publicly financed they address the question of social inequality. However, social actors involved in socially innovative practices find themselves with important opportunities and constraints in the achievement of their projects. Many of these opportunities and constraints are related to how institutions respond to innovation. But also to how civil society organizations approach institutions. We have seen that in Barcelona local institutions have supported these experiences, contributing to their sustainability, although not without conflict and negotiation. So what are the lessons to be learned from examining these cases?

There are more ways for urban regeneration than just top-down prestigious cultural interventions. Social innovative strategies do develop from active citizens. It is important, however, that civil society organizations insist on public commitment to the development of these initiatives. It is also necessary for both parties - citizens and institutions- to take into account that the process of consolidating the project may involve conflict. The cases examined show that there may be phases of misunderstanding and open conflict before reaching agreements on the governance of spaces of social innovation. In both cases, for instance, there were episodes when the civic platforms of committed neighbors interested in participating in such management had to generate protest movements to claim their own role in the transformation of the industrial space into cultural space. Therefore, governance of social innovation projects may involve innovation in governance.

On the basis of our research and similar studies referred to above we argue that the institutionalization of socially innovative practices is crucial for social innovation projects to endure and for achieving long-term effects. Institutionalization lies in recognition of objectives and actors as legitimate and worthy of support by public authorities. At the outset institutions may be receptive to bottom-up initiatives and in some cases incorporate some of the innovative practices into policy making. However, what is really needed is a "bottom-linked" process, which makes socially creative practices sustainable. The sustainability of projects developed locally at the neighbourhood level is likely to need up-scaling of support -financial and political- to city or even to metropolitan and regional levels when multi-level governance is involved.

The cultural values guiding urban regeneration do not have to be those that underlie urban competitiveness and that favour cultural-elite professionals. Alternative 
values can also guide urban cultural regeneration. We have presented the two casestudies as examples of a particular value bias; values pertaining to the realms of equity, intercultural interaction, democracy and empowerment, and oriented toward progressive social change towards the 'just city'. We have also considered a second dimension, the extent to which these practices have penetrated the public sphere. (Vicari and Tornaghi, 2013. 264). Our examples show the relevance of actors' clear objectives and the commitment of institutions to social cohesion and social sustainability in neighbourhoods.

\section{References}

Ajuntament de Barcelona, (2014) Statistics Department. http://www.bcn.cat/estadistica/catala/dades/index.htm (accessed 7 June 2014)

André, I., A, Abreu \& A. Carmo (2013) Social innovation through the arts in rural areas: the case of Montemor-o-Novo. In Moulaert, F., D. MacCallum, A. Mehmood, \& A. Hamdocuch (eds) (2013) The International Handbook of Social Innovation. Cheltenham. Edgar Elgar, 242-255.

Bassett et al. (2005) Urban Dilemmas of Competition and Cohesion in Cultural Policy. In Buck, N., I. Gordon, A. Harding \& I. Turok (eds). Changing Cities. Houndsmills. Palgrave, 132-153.

Benach, N. (2000). Nuevos espacios de consumo y construcción de imagen de la ciudad en Barcelona. Estudios Geográficos, LXI, 189-205.

Buck, N., I. Gordon, A. Harding \& I. Turok (eds) (2004) Changing Cities. Rethinking urban competitiveness, cohesion and governance. Houndsmills. Palgrave

Crouch, C. \& P. Le Galès (2012) Cities as national champions? Journal of European Public Policy, 19 (3), 405-419.

Cook, R. \& E. Swyngedouw (2012) Cities, Social Cohesion and the Environment: Towards a Future Research Agenda. Urban Studies, 49 (9) July, 1959-1979.

Degen, M. (2008) Sensing Cities: Regenerating Public Life in Barcelona and Manchester. London: Routledge.

Degen, M. \& M. García (2012) The Transformation of the 'Barcelona model': An Analysis of Culture, Urban Regeneration and Governance. International Journal of Urban and Regional Research, 36 (5), 1022-1038.

D’Ovidio, M. \& M. Pradel (2012) Social innovation and institutionalisation in the 
cognitive-cultural economy: Two contrasting experiences from Southern Europe. Cities, 1-8.

Eizaguirre, S. (2012) Innovació social i governança urbana.' Entitats socialment creatives a Barcelona i Bilbao. PhD Thesis defended 5th July 2012. Universitat de Barcelona.

Eizaguirre, S., M. Pradel, A. Terrones, X. Martinez-Celorrio \& M. García (2012) Multilevel Goverance and Social Cohesion: Bringing Back Conflict in Citizenship Practices Urban Studies, 49(9), 1999-2016.

Evans, G. (2009) Creative Cities, Creative Spaces and Urban Policy. Urban Studies, 46, 1003-1040.

Fainstein, S. (2001) Competitiveness, Cohesion and Governance: Their Implications for Social Justice. International Journal of Urban and Regional Research, 25 (4), 884-88.

Fainstein, S. (2005) Cities and Diversity. Should We Want It? Can We Plan For It? Urban Affairs Review, 41(1), 3-19.

Fainstein. S. (2010) The Just City. Ithaca. New York. Cornell University Press.

Fainstein, S. \& F. Díaz (2008) The New Mega-Projects: Genesis and Impacts. International Journal of Urban and Regional Research, 32 (4), 759-767.

Florida, R. (2002) The Economic Geography of Talent. Annals of the Association of American Geographers, 92(4), 743-45.

Garcia, B. (2004) Cultural policy and urban regeneration in Western European cities: lessons from experience, prospects for the future. Local Economy, 19(4) 312-326.

García, M. (2006) Citizenship Practices and Urban Government. Urban Studies, 43(4): 745-765

García, M. \& D. Judd (2012) The Competitive City. In K. Mossberger, P. John \& S. Clarke (eds), The (Oxford) Handbook of Urban Politics. Oxford. Oxford University Press, 486500.

Healey, P. (2004) Creativity and urban governance. Policy studies, 25 (2), 87-102.

Isin, E.F. (ed) (2000) Democracy, Citizenship and the Global City. London, Routledge. 
Jakob, D. (2010) Constructing the creative neighborhood: Hopes and limitations of creative city policies in Berlin. City, Culture and Society, 1(4), 193-198.

Krueger, R. \& S. Buckinham (2012) Towards a 'Consensual' Urban Politics? Creative Planning, Urban Sustainability and Regional Development. International Journal of Urban and Regional Research, 36(3), 486-503.

Landry, C. (2000) The creative City: a toolkit for urban innovators. London, Comedia and Earthscan Publications.

Logan, J. \& H. Molotch, (1987) Urban fortunes: the political economy of place. Berkeley, CA, University of California Press.

Lukes, S. (1971) Social and moral tolerance. Government and Opposition, 6(2), 224228).

Klein, J-L., J-L. Laville \& F. Moulaert,(2014) L'Innovation sociale. Editions Erès, Paris, France.

McCarthy, J. (2006) Regeneration of cultural quarters: Public art for place image or place identity. Journal of Urban Design, 11 (2), 243-262.

Markusen, A. (2006) Cultural planning and the creative city. Paper presented at the annual meeting of the American Collegiate Schools of Planning. Fort Worth, Texas. November 12.

Martí-Costa, M. \& M. Pradel (2012) The Knowledge City Against Urban Creativity? Artists' Workshops and Urban Regeneration in Barcelona. European Urban and Regional Studies, 19(1), 92-108.

Mehmood, A. \& C. Parra (2013) Social innovation in an unsustainable world. In Moulaert, F., D. MacCallum, A. Mehmood \& A. Hamdocuch (eds) (2013) The International Handbook of Social Innovation. Cheltenham. Edgar Elgar, 53-66.

Miciukiewicz, F. et al. (2012) Problematising Urban Cohesion: A Transdisciplinary Endeavour. Urban Studies, 49(9), 1855-1872.

Miles, S. \& R. Paddison (2005): Introduction: the rise and rise of culture-led urban regeneration. Urban Studies, 42 (5/6), 833-839.

Miles, M. (2005) Interruptions: Testing the Rhetoric of Culturally Led Urban Development. Urban Studies, 42, (5/6), 889-911. 
Mingione, E. \& S. Vicari Haddock. (2014) Politiche urbane e innovazione sociale. In Calafati A. (a cura di) Verso l'agenda urbana italiana. Milano. Donzelli.

Moix, LI. (2009) Fabra i Coats, buque insignia de la red de fábricas de creación, ya tiene plan de reforma. In La Vanguardia, 24/09/2009.

http://www.lavanguardia.com/cultura/noticias/20090924/53790676600/fabra-i-coatsbuque-insignia-de-la-red-de-fabricas-de-creacion-ya-tiene-plan-de-reforma-barcelonapl.html. Accessed 9 June 2014.

Moulaert, F., D. MacCallum, A. Mehmood \& A. Hamdocuch (eds) (2013) The International Handbook of Social Innovation. Cheltenham. Edgar Elgar.

Moulaert, F. \& J. Nussbaumer (2005). Defining the Social Economy and its Governance at the Neighbourhood Level: a Methodological Reflection. Urban Studies, 42 (11), 2071-2088.

Novy, J. \& C. Colomb (2013) Struggling for the Right to the (Creative) City in Berlin and Hamburg: New Urban Social Movements, New 'Spaces of Hope? International Journal of Urban and Regional Research 37(5), 1816-1838.

Oosterlynck, S., Y. Kazepov, A. Novy \& P. Cools (2013) The butterfly and the elephant: local social innovation, the welfare state and new poverty dynamics. ImPRovE Project. Working Paper, no 13/3 April, http://improved-research.eu

Peck, J. (2005) Struggling with the creative class. International Journal of Urban and Regional Research, 29(4), 740-770.

Pierre, J. \& B. G. Peters (2012) Urban Governance. In K. Mossberger, P. John \& S. Clarke (eds), The (Oxford) Handbook of Urban Politics. Oxford. Oxford University Press, 71-86.

Pradel, M., M. García \& S. Eizaguirre, (2013) Theorizing multi-level governance in social innovation dynamics. In F. Moulaert, D. MacCallum, A. Mehmood \& A. Hamdocuch (eds) The International Handbook of Social Innovation. Cheltenham. Edgar Elgar, 155168.

Pratt, A C (2010) Creative cities: Tensions within and between social, cultural and economic development: A critical reading of the UK experience. City, Culture and Society 1 (1) 13-20.

Pratt, A C (2011) The cultural contradictions of the creative city. City, Culture and Society 2(3), 123-130. 
Pratt, A C (2013) Reconceptualising the relationship between the creative economy and the city: Learning from the financial crisis, Cities 33, 86-95.

Rodriguez-Morató, A. (2008) La emergencia de una capital cultural Europea (The emergence of a European cultural capital). In M. García and M. Degen (eds) La Metaciudad: Barcelona. Transformación de una metrópolis (The meta-city: Barcelona. Transformation of a metrópolis). Barcelona. Antropos, 45-64.

Sánchez Belando, M V (2015) Las Políticas culturales de proximidad en el Paradigma de la ciudad creativa: el caso del programa de centros cívicos en la ciudad de Barcelona" Política y Sociedad 52(1) 125-152.

Sassen, S (2010) The city: Its return as a lens for social theory. City, Culture and Society, $1(1), 3-11$.

Savitche, H.V. \& P. Kantor (2002) Cities in the International Marketplace: The Political Economy of Urban Development in North America and Western Europe. Princeton, NJ. Princeton University Press.

Scott, A.J. (2008) Resurgent Metropolis: Economy, Society and Urbanization in Interconnected World. International Journal of Urban and Regional Research, 32(3), 548-64.

Scott, A.J. (1997) The Cultural Economy of Cities. International Journal of Urban and Regional Research, 21 (2), 323-339.

Storper, M. \& M. Manville (2006) Behaviour, Preferences and Cities : Urban Theory andUrban Resurgence. Urban Studies, 2006, 43 (8), 1247-1274

Storper, M (2013) Keys to the City: How Economics, Institutions, Social Interaction, and Politics Shape Development. Princeton. Princeton University Press.

Tremblay, D-G. \& T. Pilati (2013) Social Innovation through arts and creativity. In F. Moulaert, D. MacCallum, A. Mehmood \& A. Hamdocuch (eds) The International Handbook of Social Innovation. Cheltenham. Edgar Elgar, 67-79.

Vicari Haddock, S. \& C. Tornaghi, (2013) A transversal reading of social innovation in European cities. In F. Moulaert, D. MacCallum, A. Mehmood \& A. Hamdocuch (eds) The International Handbook of Social Innovation. Cheltenham. Edgar Elgar, 264-273.

Young Foundation (2010) The Open Book of Social Innovation. NESTA.

Zukin, S. (1995) The Cultures of Cities. Oxford, Blackwell. 
Zukin, S. \& L. Braslow (2011) The life cycle of New York's creative districts: Reflections on the unanticipated consequences of unplanned cultural zones. City, Culture and Society, 2(3) 131-140. 